\title{
Health equality, social justice and the poverty of autonomy
}

Article

Accepted Version

Newdick, C. (2017) Health equality, social justice and the poverty of autonomy. Health Economics, Policy and Law, 12 (4). pp. 411-433. ISSN 1744-134X doi:

https://doi.org/10.1017/S1744133117000093 Available at https://centaur.reading.ac.uk/70106/

It is advisable to refer to the publisher's version if you intend to cite from the work. See Guidance on citing.

To link to this article DOI: http://dx.doi.org/10.1017/S1744133117000093

Publisher: Cambridge University Press

All outputs in CentAUR are protected by Intellectual Property Rights law, including copyright law. Copyright and IPR is retained by the creators or other copyright holders. Terms and conditions for use of this material are defined in the End User Agreement.

\section{www.reading.ac.uk/centaur}

\section{CentAUR}

Central Archive at the University of Reading

Reading's research outputs online 


\section{Health equality, social justice and the poverty of autonomy}

Abstract: How does the concept of autonomy assist public responses to 'lifestyle' diseases? Autonomy is fundamental to bioethics, but its emphasis on self-determination and individuality hardly supports public health policies to eat and drink less, and take more exercise. Autonomy rejects a 'nanny' state. Yet, the cost of diseases caused by obesity is increasing to individuals personally and to public health systems generally. Health care systems are under mounting and unsustainable pressure. What is the proper responsibility of individuals, governments and corporate interests working within a global trading environment? When public health care resources are unlikely to increase, we cannot afford to be so diffident to the cost of avoidable diseases.

\section{A Introduction}

What richer countries used to call "diseases of affluence" (Porter, 2003), such as stroke, diabetes, cancer and heart disease have become a global phenomenon. The incidence of diabetes alone has nearly doubled since 1980 , rising from $4.7 \%$ to $8.5 \%$ in the adult population (WHO, 2016). These diseases are caused by smoking, excessive alcohol consumption, over eating and lack of exercise. Are these private matters for individual autonomy in which the state has no business to interfere, or do public interests demand a community response? The question involves tensions between freedom and paternalism, liberty and equality, autonomy and citizenship which lie at the root of public health ethics. In the NHS, tobacco, physical inactivity, excess alcohol consumption and poor diet are estimated to account for around $£ 9.4$ billion in direct costs to the economy annually (Department of Health, 2010). The balance sheet of death and disability adjusted life years (DALYs) in the UK is explained as follows (WHO, 2005):

\begin{tabular}{|l|c|l|c|}
\hline Risk Factor & $\begin{array}{c}\% \text { of Total } \\
\text { Deaths }\end{array}$ & Risk Factor & $\begin{array}{c}\% \text { of Total } \\
\text { DALYs }\end{array}$ \\
\hline Tobacco & $24.3 \%$ & Tobacco & $14.2 \%$ \\
\hline High blood pressure & $19.4 \%$ & High blood pressure & $8.6 \%$ \\
\hline High cholesterol & $13.3 \%$ & High cholesterol & $6.9 \%$ \\
\hline High BMI & $8.0 \%$ & High BMI & $6.3 \%$ \\
\hline Physical inactivity & $5.5 \%$ & Alcohol & $5.2 \%$ \\
\hline Low fruit and vegetable intake & $4.0 \%$ & Physical inactivity & $3.1 \%$ \\
\hline Occupational airborne particulate matter & $0.6 \%$ & Illicit drugs & $2.6 \%$ \\
\hline Urban outdoor air pollution & $0.6 \%$ & Low fruit and vegetable intake & $2.2 \%$ \\
\hline Unsafe sex & $0.6 \%$ & Unsafe sex & $0.8 \%$ \\
\hline Illicit drugs & $0.4 \%$ & Occupational airborne particulate matter & $0.6 \%$ \\
\hline Total for these 10 risk factors & $76.7 \%$ & Total for these 10 risk factors & $50.5 \%$ \\
\hline
\end{tabular}

In addition, disease is distributed highly unevenly. Although aggregate standards of health continue to improve, health inequalities between rich and poor are increasing. Indeed, policies to reduce health inequality often benefit most those least in need of assistance. As the House of Commons Health Committee said in 2009:

Health in the UK is improving, but over the last ten years health inequalities between the social classes have widened - the gap has increased by $4 \%$ amongst 
men and by $11 \%$ amongst women... Inequalities have worsened not because the health of the poor is getting worse or even staying the same, but because the rate of gain amongst more advantaged groups (House of Commons, 2008-09). ${ }^{1}$

The disparities are described by the following graph (OECD, 2009).

Occupational group differences in life expectancy, England and Wales, 2002-2005

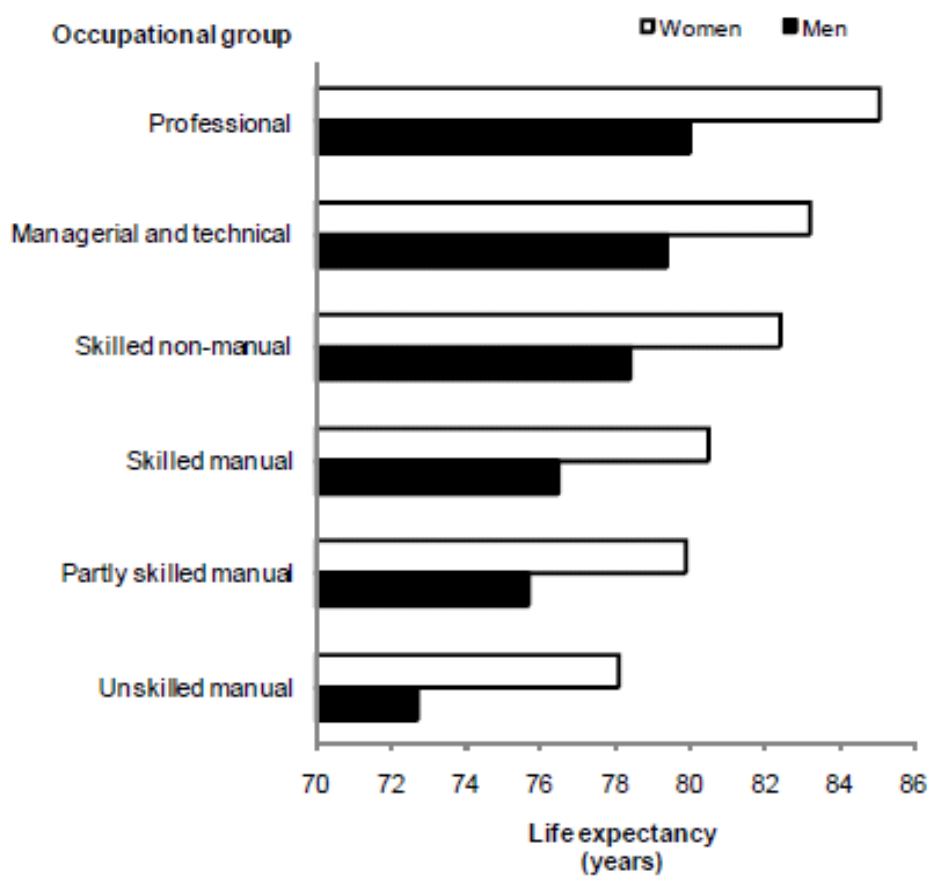

As in many industrialised countries, the most disadvantaged people in the UK suffer significantly higher levels of mortality and morbidity than wealthier people. "In the early 2000s, in England, people living in the poorest neighbourhoods could on average expect to die seven years earlier than people living in the richest neighbourhoods and spend far more of their lives with ill health" (National Audit Office, 2010-11). If everyone's health is getting better, does it matter if health inequality is getting worse (Mechanic, 2010)? Rawls' "difference principle" appears to disregard considerable inequality so long as the worst off derive some benefit from the gains made by the wealthiest. "While many Rawlsians may hope and expect that the Difference Principle... will result in a decent minimum for the worst off, the achievement of that result is no part of its rationale" (Powers et al., 2006, 31). Is this sufficient? Or do civilised societies have powerful interests in equality? We recognised the significance of the question in 1977 with the appointment of Sir Douglas Black to examine inequalities in health (Whitehead, 1988), yet health disparities continue to widen (House of Commons, 2008-09). In 2006, the European Charter on Counteracting Obesity (WHO, 2006) found, perhaps overoptimistically, that: "[t]he obesity epidemic is reversible... Visible progress, especially relating to children and adolescents, should be achievable in most countries in the next 45 years and it should be possible to reverse the trend by 2015 at the latest." Clearly, the

It is estimated that $80-85 \%$ of variation in mortality statistics are caused by socio-economic factors outside the control of health care, such as poverty, intelligence and ethnicity (House of Commons Health Committee, 2008-09). 
problem has tenacious roots. Public information campaigns are helpful to some extent, but they benefit higher socio-economic groups most and are less effective in changing the behaviour of those for whom they are primarily intended (House of Commons, 2008-09). Do these disparities reflect an autonomous right of people to live for today and disregard the future? Or does health inequality reflect a systemic inequity so that to compare "lifestyle" with choosing a pair of flares or a striped shirt is wrong because health inequalities engage deeper issues of citizenship?

This is not just about bioethics; there is an economic imperative. The effects of vascular disease, including coronary heart disease, stroke, diabetes and kidney disease are linked by common risk factors such as obesity, physical inactivity, smoking, high blood pressure and glucose regulation. These currently burden over 4 million people in England with illness, cause $36 \%$ of deaths (170,000 a year in England) and are responsible for a fifth of all hospital admissions (House of Commons, 2008-09).

In England, almost a quarter of adults and almost a sixth of children under the age of 11 are obese. It is predicted that by $2050,60 \%$ of adult men, $50 \%$ of adult women and $25 \%$ of children may be obese... Around $58 \%$ of the incidences of type 2 diabetes, $21 \%$ of cases of heart disease and between $8 \%$ and $42 \%$ of cancers are attributable to excess body fat (NICE, 2005, 2).

Current investment in the NHS is about $£ 120$ billion. The government estimates that the costs of treating the various conditions arising from obesity will increase from $£ 4.2$ billion in 2007 to $£ 9.7$ billion by 2050 (imposing costs on the wider economy of $£ 49.9$ billion) during a period of time in which government income will not increase (Government Office for Science, 2013). The Office for Budget Responsibility forecasts that the economic consequences of our ageing population will render current patterns of public welfare spending "unsustainable" as larger proportions of expenditure are required for age-related needs such as social care, pensions and health care. Assuming government revenues remain roughly stable as a share of national income, the additional demand for services will set public sector debt on an unmanageable upward trajectory (Office of Budget Responsibility, 2012, paras 48-50). Ethics aside, therefore, reasons of economics articulate the need to reduce the burden of chronic disease by investing in preventive care and health promotion. Yet, from the total invested in the NHS, we spend relatively little on public health.

Public health spending has doubled over the last seven years as a share of total health spending. It has increased to $£ 4.7$ billion (including pharmaceuticals but excluding secondary prevention) and $£ 3.4$ billion (excluding pharmaceuticals and secondary prevention), and the share of total health expenditure spent on public health and prevention in England had doubled over seven years to 3.6 per cent for 2006-07 (Cm 7621, 2009, para 54). ${ }^{2}$

Globally, it is estimated the health-care spending on diabetes more than tripled between 2003-13, to around US\$825 billion today (WHO, 2016) and the upward trend is set to continue. The need for additional expenditure on health promotion and preventive care presents questions governments are loath to answer. For example, if expenditure on preventive health should expand, as a necessary investment in the future, will this require a commensurate contraction of resources for those with health care needs today? How

2 These figures are taken from Prevention and Preventative Spending Health England Report No 4 (2009), 4, which notes that: "The average share of public health spending for OECD countries as measured by the survey was 2.9 per cent." 
should social and economic rights to equality of health interact with individual civil rights to be left alone? How should public policy regulate multinational producers whose commercial success depends so much on food and drink rich in sugar, salt and fat? And if we intend future generations of people to benefit from the health systems we enjoy today, what duties do we owe those yet to be born to preserve our current arrangements in a sustainable condition?

These questions do not attract much attention in health law and ethics. Medical ethics emphasises the rights of individuals in the doctor-patient relationship. Less attention is given to the institutional implications of public health ethics for freedom, or the need to reduce "avoidable" diseases which disproportionately affect the lives of poorer people. As Daniels comments (Daniels, 2008, 81), "unfortunately... these questions have been almost totally ignored within the field of bioethics, as well as within ethics and political philosophy generally."

Bioethics has been quick to focus on exotic new medical technologies and how they might affect our lives. It has paid considerable attention to the doctor-patient relationship and how changes in the health system affect it. With some significant exceptions, it has not looked "upstream" from the point of view of the delivery of medical services to the role of the health care system in delivering improved population health. It has even more rarely looked further upstream to social arrangements that determine the health achievement of societies (Daniels et al., 2006, 64).

And as Martin and Coker observe: "Few health law programs have ventured into the obscure and unbounded terrain of public health law because of difficulties of knowing where to start, what to include, and what constitutes the essence of public health law" (Martin and Coker, 2006, 81). Instead, bioethics has been overwhelmed by the individualistic priorities of medical ethics, ie medical negligence, informed consent and confidentiality (Dawson, 2010). This is fine so far as it goes - there is much merit in distinguishing the relative rights and duties of doctors and patients. But it goes nowhere near far enough. It ignores the concept of "public" health ethics which describes a relationship between the individual and the state (Coggon, 2012) and a normative duty to promote health equality (Deaton, 2007; Verweij, 2009). As the Marmot Review says:

Health inequalities are a matter of social justice... Inequalities are a matter of life and death, of health and sickness, of well-being and misery. The fact that in England today people from different socio-economic groups experience avoidable differences in health, well-being and length of life is, quite simply, unfair and unacceptable...(Marmot Review, 2010)

Discouraged, perhaps, by bioethics' hesitancy in this field, governments struggle to respond to this challenge. What are the obstacles confronting a coherent response to the needs of public health today? When does government have a legitimate interest in my lifestyle? Should my freedom today ever be regulated to protect my autonomy tomorrow? How can individual rights be balanced with the public interest in a public health care system? With these questions in mind, we consider (B) liberty and individual responsibility, (C) autonomy in community and (D) democratic autonomy and international commerce and (E) communitarian autonomy and public health ethics. I argue that autonomy should embrace the wider social, political and commercial contexts in which people flourish and have regard to both the future interests of individuals themselves and the needs of the community as a whole. 


\section{B. LIBERTY AND INDIVIDUAL RESPONSIBILITY}

Contemporary medical ethics, with its roots in the paradigm of liberal individualism, understand law's primary purpose as the promotion individual autonomy and minimal interference with self-determination. Government's role is to facilitate, not interfere. Policies which restrict individual liberty are naturally subordinate to those which promote the right to be let alone. An "ideal-type" of autonomy is described by Isaiah Berlin when he says:

I wish my life and decision to depend on myself, not external forces of whatever kind. I wish to be the instrument of my own, not of other men's acts of will. I wish to be subject, not object; to be moved by reasons, by conscious purposes, which are my own, not by causes which affect me, as it were, from outside...(Berlin, 1969)

Echoeing J.S. Mill's "harm" principle, this emphasises a negative right, that the state has no business "nannying" competent adults about their health and well-being. Autonomy respects agency, our capacity for control and our right to govern our destiny, free from paternalistic restraint. A modification of this approach, conceding the need for state "paternalism" in a limited range of circumstances, supports government intervention when it addresses a failure of judgment by an individual in a way that furthers the individual's own good (Le Grand and New, 2016). On this basis, a case is made for restricting the right to smoke and to encourage investment in a pension, but there is clear hesitancy to take the matter further. Autonomy in this guise might accept that inequality often damages people's health. Equally, however, it may also argue that, unless incompetent, individuals remain responsible for the consequences of their actions. Respect for capacity brings responsibility for untoward outcomes. If poor health status results from autonomous decision-making, then we may disentitle ourselves from the same rights of access to public health care as others; it would be pernicious to infantilise people by pretending they are not responsible for the consequences of their actions. Social policy, it may be argued, should educate and inform (such as by warnings on cigarettes and alcohol), but it should respect autonomy and the rights of individuals to decide for themselves how they live, the quality and, perhaps, the length of their lives. To do otherwise would permit doctors to assume disproportionate and unwarranted power over personal choices which have nothing to do with clinicians (Epstein, 2004).

Support for this view, that those who suffer from diseases caused by their own "lifestyle" should be responsible for their consequences, is available from Ronald Dworkin who distinguishes between "luck" and "option" egalitarianism, ie between diseases arising through "brute" bad luck, and those caused by personal choices, or options. If we choose to act in ways that cause illness, individual rights to publicly funded welfare should be affected (R. Dworkin, 2000). People should bear the consequences of the choices they make. The NHS Constitution adds further credibility when it states that: "You should recognise that you can make a significant contribution to your own, and your family's, good health and well-being, and take some personal responsibility for it" (NHS Constitution, 2015). Such an approach might seek to distinguish between, for example, the illnesses caused by congenital conditions such as asthma, type 1 diabetes, and depression; and those that arise from lifestyle or personal behaviour, such as type 2 diabetes caused by obesity, lung cancer caused by smoking, and cardiovascular disease caused by diet and lack of exercise (except, of course, that attributing exact cause in each is often impossible). Following Ronald Dworkin, whilst the first is a public responsibility, the latter may transfer as a private matter to individuals to resolve. In 
respect of "option" diseases, perhaps "higher-risk" patients should purchase additional health insurance, pay more for goods and services or suffer public shame (Singer, 2015). Perhaps welfare benefits should be withdrawn for failure to accept treatment for drug or alcohol dependency (Home Office, 2010; R. Hardin, 1993), or access to health care could be restricted to those who achieve specific clinical preconditions for treatment (eg in respect of their weight, or cholesterol levels)(BBC, 2016). For example, West Virginia in the US, makes health care entitlements dependent on patients achieving specific clinical objectives (Patrick, 2008). Social welfare could be made dependent on "contractual" agreements with individuals so as to focus public resources upon those who act responsibly by working hard to "re-enter society and... become useful, autonomous, and self-reliant..." (Veitch, 2011, 198, balancing this "exclusionary" view of citizenship, with a more "inclusive" vision promoting equality as a goal in itself.) So too, the Welfare Reform Act 2007 may make Jobseekers Allowance conditional upon gaining work experience with employers, or working pro bono for community projects (Brown, 2009). ${ }^{3}$

But this "atomistic" view, which demonises needy individuals, has severe limitations. Berlin was responding to the politics of intolerance and hostility of the Cold War; he was not making a plea for anarchy. As he explained, it is profoundly mistaken to pretend that autonomy permits people freedom to fulfill their lives without constraints: "the very concept of an ideal life, a life in which nothing of value need ever be lost or sacrificed, in which all rational... wishes must be capable of being truly satisfied... is not merely utopian, but incoherent. The need to choose, to sacrifice some ultimate values to others, turns out to be a permanent characteristic of the human predicament." To promise autonomy, therefore, as if it is a "frictionless medium" which lubricates human flourishing is "to dehumanize men, to turn them into the brainwashed, contented beings of Aldous Huxley's celebrated totalitarian nightmare.” People must adjust between multiple choices both to accommodate their own aspirations in life and the legitimate needs of others.

$[F]$ reedom is not the only value that can or should determine behavior... the issue is not one between negative freedom as an absolute value and other, inferior, values. It is far more complex and painful. One freedom may abort another; one freedom may obstruct or fail to create the conditions which make other freedoms, or a larger degree of freedom, of freedom for more persons, possible... But beyond all these there is an acuter issue: the paramount need to satisfy the claims of other, no less ultimate values: justice, happiness, love, the realization of capacities to create new things and experiences and ideas, the discovery of truth (Berlin, 1975, li-lvi).

This concedes the need for compromise amongst a range competing, yet incompatible legitimate demands. For example, we do not have unrestricted autonomy over our private wealth because it may be taxed to support publicly funded health care, education and transport services. We may not build on our private land because planning restrictions benefit everyone. We regulate our environment and health and safety, we protect employees from exploitative employers, tenants from exploitative landlords and consumers from exploitative contracts. By endorsing interventions of these kinds, Berlin rejected the notion that he was undermining government. His support for social and economic rights was based on "the ideal of social solidarity; the need to provide for the

$3 \quad$ In Van de Mussele v Belgium (1983), the duty of pupil barristers to undertake unpaid public work was approved for being "founded on a conception of social solidarity." 
bodies and minds of as many humans as possible, and not only of members of a privileged class" (Berlin, 1975, liv). As Gray rightly observes, therefore: "[a]utonomy is not a good that can be accorded priority over other values... Just as there are incompatible negative liberties, so there are rival autonomies" (Gray, 2000).

\section{AUTONOMY IN COMMUNITY}

In any case, the view of autonomy that seeks to maximize the moral force of individual volition by minimising the state's responsibilities for equality, assumes a great deal about "free will" that might be contested by psychologists (eg Freud and Marcuse), economists (eg Marx and Hayek), and political theorists (eg Hobbes and Rousseau) (Muller, 2002). In truth, as Gerald Dworkin explains, the notion of autonomy is so elastic that it comfortably accommodates a wide range of differing relationships between the individual and society:

It is used sometimes as an equivalent of liberty (positive and negative in Berlin's terminology), sometimes as equivalent to self-rule or sovereignty, sometimes as identical with freedom of the will. It is equated with dignity, integrity, individuality, independence, responsibility, and self-knowledge. It is identified with qualities of self-assertion, with critical reflection, with freedom from obligation, with absence of external causation, with knowledge of one's own interests... About the only features held constant from one to another are that autonomy is a feature of persons and that it is a desirable quality to have (G. Dworkin, 1988; and see Le Grand and New, 2015, categorising paternalism). Whichever conception one prefers, individualistic claims for autonomy are unsatisfactory if they "decontextualize" people from the community in which they live by removing their interest in society (McLean, 2010). To explain autonomy in terms of "laissez-faire individualism" wrongly judges personal responsibility in terms of the "unsituated and demonic character of classical rationality" (Hurley, 2011, 202). More helpful is the idea of "ecological rationality" which recognises the exogenous forces that influence personal decision-making. It acknowledges how our environment shapes our behaviour, the heuristics and biases that bear on individual cognition and the various "nudges" which influence rational choices. "Traditional liberalism tends to view government as the primary source of interference... Ecological liberalism should instead view government as having a counter-manipulative and positive role in the public ecology of responsibility" (Hurley, 2011, 209). Behavioural psychology might regard bioethics' tendency to prioritise autonomy as an example of an analytical "framing" of a concept in a way that nudges responses towards the ends it seeks to achieve (Kahneman, 2011). To regard behaviour which arises from unconscious influences to be a strong expression of personal autonomy is absurd. Behaviour is heavily shaped by the habits of family and friends (Mulvaney-Day et al., 2009). As the Marmot review found:

health inequalities do not arise by chance, and they cannot be attributed simply to genetic makeup, 'bad' behaviour, or difficulties in access to medical care, important as these factors may be. Social and economic differences in health status reflect, and are caused by, social and economic inequalities in society..." (Marmot Review, 2010)

Research published by the UK Cabinet Office supports precisely this analysis. Autonomy is not an especially persuasive explanation for the choices we make. By contrast, "[b]ehavioural approaches embody a line of thinking that moves from the idea of an autonomous individual making rational decisions to a 'situated' decision-maker, much of 
whose behaviour is automatic and influenced by their 'choice environment'... What we eat, where we go, what we do - most of us are creatures of habit and, in a very general sense, the environment that we live in" (Dolan et al., 2010, 73). Penalising individuals within the luck/option dichotomy will often wrongly blame as "optional," decisions which are predominantly caused by our situation and surroundings (Kahneman, 1982). Autonomy is mistaken, therefore, if it assumes that the opportunities offered in life are equally available to everyone because health achievement is a good proxy measure of our capacity to choose our lifestyle; "smoking and other addictive behaviour can also be seen in terms of a generated 'unfreedom' to conquer the habit" (Sen 2006, 23).

More persuasive, therefore, are notions of principled autonomy which describe autonomy within a community of values on which we could all think and act: "Autonomy in thinking... is to conduct thinking... on principles on which all others... could also conduct their thinking. Autonomy in action is... to act on principles on which all others could act" (O’Neill, 2002, 94). This could discount as autonomous, actions "all others" would have to reject for contradicting their own rights and interests. Brazier agrees: "[u]nfettered, non-reflective choice, the satisfaction of preferences, is not, within such definitions, the essence of autonomy. Self-mastery and self-control entail the requirement at least to consider self-sacrifice. Responsibility for 'free' choices demands consideration of how those choices affect others" (Brazier, 2006, 400-1). Precisely this interpretation has been given to Mill's defence of liberty (Powers, 2009) which Gostin develops as an argument for an ethics of "hard paternalism" (Gostin, et al., 2009). Autonomy in this political and relational sense expresses values of citizenship and reciprocity in the longterm, which recognises the need for balance and compromise between incompatible claims. This lies at the heart of Sandell's critique of Rawls' individualistic, "veil of ignorance" approach to justice (Sandell, 1998), ie that it is based on an untenable fiction of individuals agreeing about the benefits of living in "communities" led by "governments," about which, by definition, they can have little imagination. Ideas of freedom and "individuality" only make sense in the context of "society." Autonomy should also be interested in the position of disadvantaged communities and their capacity for self-determination. The focus is not simply "negative," civil rights of freedom from interference, but on social and economic rights to equality and distributive justice as the source of flourishing communities.

The argument is not that individuals can have no responsibility for "lifestyle," but other factors, biological, cultural, psychological and environmental, also play a significant role. For example, the luck/option theory would have to acknowledge the impact of environment on health status and discount from our responsibility for "option illness" the brute bad luck arising from (say) discrimination from disability, age, race, or sex (Nielsen et al., 2013). In reality, a fair and consistent process for conducting such an exercise would surely be implausible, because "bad luck" and "option" lie at the opposite extremes of a highly complex spectrum of causal interactions about which objective measurement is impossible (Schmidt, 2009). Consider a woman addicted to glue-vapour. She has three children all of whom have been taken into care. Two of them have suffered brain damage in utero caused by her addiction. She is expecting a fourth child but continues to inhale glue. There is concern that she will be likely to conceive further children and continue to expose herself and her children to serious risk. Should respect for "autonomy" require us to refrain from interfering with her liberty to act in this way and to disregard the circumstances of her life, the interests of her children and her own, 
natural maternal concern $?^{4}$ A similar problem arose in Condliff $v$ North Staffordshire PCT. The claimant suffered diabetes. He had a fear of needles which, over many years, had made it difficult to take insulin to control his condition. He developed a gross appetite, was unable to control his diet and became obese with a body mass index (BMI) of over $40 \mathrm{~kg} / \mathrm{m} 2$. He became immobile and depressed. He suffered incontinence, but could not shower or dress himself and imposed stress on his wife on whom he was reliant for so much. He applied to the NHS for surgery to reduce the size of his stomach. ${ }^{5} \mathrm{Had}$ respect for Mr Condliff's autonomy encouraged a state of personal dependency?

Does the "luck/option" distinction assist us to understand Mr Condliff"s rights? Did his circumstances arise from his autonomous "option," or his bad luck; was it chance, or choice; genetic predisposition, or personal volition? If each explanation plays a role, how should one be set off against the other? Or was his condition "the result of people responding normally to the obesogenic environments they find themselves in" (Swinburn et al., 2011)? The luck/option distinction succeeds in imposing a disproportionate burden on individuals only by disregarding the external influences of the social determinants of health. How would the luck/option distinction apply to people whose heart disease or Alzheimer's disease in retirement was caused by their poor diet in childhood (Friedman et al., 2012; Steen et al., 2005)? In any case, penalising individuals for "option" illness may be morally repugnant for lacking in human compassion. "Most people do not insist, as a general matter, that someone who makes a bad decision thereby forfeits all claims to assistance... Such a policy would strike us as harsh, unforgiving, insensitive to context, and unduly moralistic" (Scheffler, 2005). In 2008 NICE's Citizens' Council broadly agreed that: "NICE should not take into consideration whether or not a particular condition was self-induced. It was often impossible in an individual, to decide whether the condition was dependent on their own behaviour or not; and receiving NHS care should not depend on whether people 'deserved' it or not." Gerald Dworkin also supports this view by arguing that the burdens of autonomy cannot be determined simply by focusing on the decision of single individuals at a single point in time. Instead, we should take a broader "life-time" view of autonomy by distinguishing between first order (ie, immediate) and second-order (longer-term) desires. He says:

To consider only the promotion or hindrance of first-order desires... is to ignore a crucial feature of persons, their ability to reflect upon and adopt attitudes toward their first order intentions... One may not just desire to smoke, but also desire that one may not have that desire... [Autonomy] evaluates a whole way of living one's life and can only be assessed over extended portions of a person's life... By exercising such a capacity, persons define their nature, give meaning and coherence to their lives, and take responsibility for the kind of person they are (G. Dworkin, 1988, 15-20).

Clearly, this account of autonomy offers different responses to the cases discussed above. Rather than cloak the choices I happen to make today with dubious ethical significance, autonomy should perform a more profound role by adopting an "ecological" approach to

\footnotetext{
$4 \quad$ As it did in the Canadian Supreme Court in Winnipeg Child and Family Services (Northwest Area) v. G. (D.F.) [1997], prompting discussion of the morality of offering women "cash for sterilization" (Sandell, 2012).

5 Although his health authority accepted that bariatric surgery was appropriate, it was unable to afford it until BMI was 50 or more, bearing in mind the needs of the community. The Court of Appeal dismissed Mr Condliff's application for judicial review on the ground that his rights had been considered fairly and equally with those of other patients.
} 
individuals in society by accommodating our needs and aspirations for tomorrow, including, perhaps, to health, happiness and security.

\section{DEMOCRATIC AUTONOMY AND INTERNATIONAL COMMERCE}

Does the allure of autonomy rest solely upon its ethical appeal, or are deeper forces at work inhibiting more systematic responses to concerns about inequality and opportunity? Put differently, how should autonomy respond to the systemic, global forces which exacerbate inequality and the prevalence of disease (Marmot, 2010; Picketty, 2014; Atkinson, 2015)? During most of the twentieth century, developed nations reduced social and economic inequality by investing in social welfare services too important to be left to private interests to provide. It was during this period, with the growth of concepts of public goods and services, that social and economic inequality was most significantly reduced (Polanyi, 1957). After the mid-1990s, however, a strong belief developed that markets are best at promoting public interests. Competition between private interests, it was said, would naturally drive quality up and prices down - to the benefit of the public interest. Public corporations, it was said, cannot achieve this because they are more likely to be undermined by the "knavish" self-interest of public servants (Le Grand, 2006). Much better to have private investment where producers compete for the most efficient ways to respond to public demand. Ideally, therefore, the state should promote free markets and play a minimal supervisory role. Governments can "nudge," but they should not directly presume to change individual behaviour (Thaler and Sunstein, 2009).

Milton Freidman expected the public to benefit from private competition (Friedman, 1970) as did Hayek who feared that 'the prevailing belief in 'social justice' is at present probably the gravest threat to most other values of a free civilisation" (Hayek, 1976). This describes the confidence in private incentive as the most reliable servant of public interest. But this light-touch approach to market regulation has not traced the trajectory expected of it. The global financial crisis since 2007 demonstrates why private interests are not always trustworthy. On the contrary, the process creates its own, still more powerful and predatory "knaves." As Stiglitz observes, "privatization gives rise to an unhealthy dynamic: the monopolist uses its profits to buy political influence, which extends and enhances its market power. Privatization can thus result in increased corruption in addition to a less competitive and overall less efficient economy" (Stiglitz, 2016, 194). By 2015, for example, fines for misconduct imposed on the banking sector exceeded \$235bn (International Business Times, 2015). Deregulated markets erode national political authority, widen social and economic inequality, and worsen standards of public health (Rodrik, 2011; Stiglitz, 2013). The state's power to redistribute wealth through welfare diminishes as does the proportion of employees' wages relative to the employers' overall income (OECD, 2015; Atkinson, 2015). The consequence is not more autonomy, but greater economic and welfare dependency.

We have noted the correlation between social inequality and disease. The speed and spread of non-communicable diseases is described as a "neoliberal epidemic" (Shrecker, 2016; Shrecker and Bambra, 2016). Today, problems of global access to nutritious food are no longer about famine. They concern the costs of obesity upon individuals and governments (WHO, 2016; NCD Risk Factor Collaboration, 2016; McKeon, 2015), especially in poor and disadvantaged populations (WHO, 2008). Yet, this "night-watchman" view of the state, implicitly endorsed by the classical narrative of autonomy, distances government from its citizens, diverts attention from the root causes of inequality and blames individuals when things go wrong. Young and under employed 
citizens of Southern Europe may say it has nothing to do with ethics or democracy. As states" capacity to raise taxation falters - as the "tax state" is replaced by the "debt-state" - government priorities adjust themselves to reassure international bondholders of their priority as the principal stakeholders in national wealth; or as Streek puts it, that marktvolk take priority over staatsvolk (Streek, 2013). In this way, the capacity to protect social welfare is subordinated to the need to promote corporate wellbeing (Mazzucato, 2013).

Democratic autonomy is further eroded by international economic law which restricts governments' discretion to regulate the trade and investment of multinational corporate interests. Concern is expressed, for example, about pharmaceutical companies' resistance to supply developing nations with medicines at affordable prices; destabilising speculation on the global food markets; and corporate resistance to measures to reduce consumption of alcohol, sugar, fat and salt (McGrady, 2011; Pogge, 2010). Oil and gas producers defend their pollution of the Amazonian rainforest. Mining investors in South Africa have been compensated following the Black Economic Empowerment Act 2003 for diminished profits. Tobacco manufacturers resist governments regulating cigarette packaging and food manufacturers the control of sugar, salt and fat in our diet. Although these disputes involve tension between public and private interests, they are often not heard in public courts. Instead, they may be referred to private arbitrators who comprehend the "private" dimension of disputes, but are less familiar with the notion of public interest and the duties of government. As the European Commission complains: "... arbitral tribunals, in interpreting the investment agreements, have only considered the objective of protecting the economic interests of the investors and have not balanced it against the sovereign right of States to legislate in the public interest" (European Commission, 2015). Rules of precedent do not apply to promote consistency and cases determined in public courts against private investors may be appealed to private arbitrators for a different decision, from which there may be no right of appeal. ${ }^{6}$ Doubt is expressed as to the capacity of private arbitrators to recognise and promote fundamental public interests (Kulick, 2012; Van Harten 2013). In this environment of trade and investment law too, therefore, systems which properly balance corporate and democratic authority are failing.

Globalisation requires a more far-reaching response to the governance of public interests. Little has been said about the idea of "corporate autonomy" which permits transnational corporations so much freedom to promote their private interest indifferent to its impact on public interests. The UN's Sustainable Development Goals contemplate considerable redistribution of global wealth and opportunity and a very different approach to the capacity of transnational corporations to promote their commercial interests in isolation from everything else. This suggests that rights of autonomy cannot be confined simply to the here and now without regard for the future. Autonomy needs an intergenerational component embracing the needs of those that follow us to enjoy sustainable lives, free from extreme hardship. This has implications for the "others" to

$6 \quad$ As occurred in the Australian cigarette packaging case, JT International SA v Commonwealth of Australia [2012] (unsuccessfully, albeit on a procedural point only, see PCA Case No. 2012-12). Art 53(1) of the International Centre for the Settlement of Investment Disputes provides “... the parties shall not be subject to any appeal or to any other remedy except those provided for in this Convention. Each party shall abide by and comply with the terms of the award..." 
whom autonomy must have regard, ${ }^{7}$ especially in respect of non-communicable diseases, the environment and biodiversity. The scale of corporate resistance to this profound public interest is illuminated in BAT, Philip Morris, JT, Gallagher and Imperial Tobacco $v$ Secretary of State [2016] EWHC 1169, in which tobacco manufacturers challenged the UK government's right to discourage cigarette smoking by regulating the markings on cigarette packaging. The manufacturers argued that the regulations were unlawful for restricting their right to exploit their intellectual property in trademarks. Green $\mathbf{J}$ summarized the nature of this claim as follows:

These arguments operate upon the premise that a trade mark proprietor cannot be prevented from using a trade mark at all even when it facilitates a health epidemic [40]... At base this point boils down to the correctness of the Claimants' proposition that the essence or substance of their trademarks allows them to facilitate a health epidemic... and that since they are prevented from using their property rights to do this by the Regulations those measures are unlawful... [837]. Although the proposition was comprehensively rejected by the (public) court, the manufacturers announced their intention to appeal the decision and to private, WTO arbitration (BAT, 2016). BAT articulates the version of autonomy, rejected by Isaiah Berlin, which claims private rights against public interests and challenges the democratic authority of governments to interfere. Similar resistance may be anticipated from the global food producers to the recommendations of the WHO that food and drink rich in fats, salts and sugar should be taxed at higher rates; that fresh fruit and vegetables should be subsidised; for greater engagement of government promoting healthier diets and physical activity (WHO, 2016); and to "food sovereignty" policies to promote local farming employment, improved nutrition and national democratic authority (McKeon, 2015). The UN Conference on Trade and Development recognizes the need to modify the balance of power in global commerce and for better standards of corporate social responsibility. Equally, it expects resistance from both corporations and governments themselves, "racing to the bottom" to create a corporate-friendly environment to entice large employers to move business onshore (UNCTAD, 2015). ${ }^{8}$ The invisible hand of neoliberalism, with its emphasis on corporate autonomy, small government, low taxation and limited social welfare, obstructs the democratic capacity to promote equality.

\section{E. COMMUNITARIAN AUTONOMY AND PUBLIC HEALTH ETHICS}

Autonomy presented as a strong expression of individual rights has the allure of analytical clarity, but its attraction camouflages much that is hidden. Current conceptions of autonomy are troubled by asserting a positive role for health policy to change behaviour. As the statistics on non-communicable diseases testify, efforts to reduce health inequality over the past 40 years have failed. Bruce Jennings comments that:

... the culture of autonomy has created a strange chimera as its ideal: a freestanding individual for whom privacy and autonomy are sacred virtues, independent of his community, with almost unbridled authority over his actions and with no responsibility for its consequences. It has created a society of rights

\footnotetext{
$7 \quad$ On this logic, the "greatest happiness of the greatest number" principle is duty-bound to consider the interests of those yet to be born. Discussing these rights and duties generally, see A. de-Shalit (1995). And for the consequences of our failure to confront them, see J. Diamond (2006).

$8 \quad$ Luxembourg and Ireland led the race in Europe. Jean-Claude Junker, PM of Luxembourg until 2013, became President of the European Commission.
} 
without duties or obligations; of authority without responsibility (Gaylin et al., 2003, 203).

But it is not simply that personal autonomy encourages individuals to disregard society. The argument above is that corporate autonomy distances government from its responsibility to its citizens. Market fundamentalism challenges the capacity of national politics to regulate corporate interests and instead imposes the burden of responsibility upon individuals. By contrast, a communitarian response asks "what kind of community we want to live in and uses this, rather than individual welfare exclusively, as guidance in determining social policy" (Bayer et al., 2007). Necessarily, the focus on community interests emphasises equality (alongside liberty) and government's responsibility for "positive," welfare rights (alongside negative ones), including an equal right to good health. Here, the starting point is not an autonomous individual behind a veil of ignorance, or a corporate entity promoting its own private interests, but with the civic responsibility of government. To Berlin's two concepts of liberty, Jennings proposes a third civic freedom:

The third freedom (freedom through) is a warrant to live one's life in one's own way that results from embedding that way of life in a tradition, a civic life of shared purpose, and rooting that life in membership of a broader community. Just as there are kinds of practice or activity that by their very nature cannot be done alone, so there is a kind of freedom that subsists not in separation from others but through connection with them (Jennings, 2009, 130).

This helps too, provided the civic tradition embraces corporate responsibilities to foster analogous goals of equality and social cohesion. Some may say that government should get out of the way of market forces and community values (Holland, 2007). After all, who will set these "shared purposes" and where is the balance between legitimate regulation and the freedom to be let alone (Herring, 2016)? Certainly these are difficult questions, but if we concede that autonomy and paternalism co-exist on a spectrum which embraces broader political values, we may be content to give public interests greater prominence in promoting health and equality in the same way as we regulate trade, taxation and town planning (Wilson, 2011; Wilkinson and Pickett, 2010).

This is where the tidiness of abstract theory ceases to assist the search for plausible solutions. How should public health policy-makers proceed when we move from the negative rights to be free from unwanted interference toward positive rights of equality and distributive justice? For example, when may policy to promote public health in the long-term impinge on my "life-style" choices today, or restrict the rights of corporate interests to engage in "free" trade? Sen usefully assists this debate by distinguishing two mechanisms for theorizing about justice based on "ideal" and "nonideal" approaches to theory. The first concerns models based on abstract, ideal-theories founded on fundamental values, which he calls "transcendental institutionalism" (Sen, 2009). In this camp, Sen places, for example, Hobbes, Rousseau, Locke, Kant, Rawls and Ronald Dworkin. Ideological adherence to neoliberal economics is a further example (see Kay, 2015; Rodrik, 2012, Stiglitz, 2013) of "abstraction away [ie] a technique in argumentation that 'purifies' thought by eradicating supposedly irrelevant, mundane, or trivial conceptual features to allow for clearer analysis" (Coggon, 2012, 210).

Autonomy presented in its decontextualised form enables "purists" to marginalise the consequences of neoliberal economic policy for ordinary people in terms of unemployment, homelessness and economic dependency. And it encourages indifference to other aspects of civilised life such as dignity, equality and community. This creates an 
artificial normative framework better suited to "government within some alien place, reflective only of an incomplete picture of the important aspects of the society we live in" (Coggon, 2012, 213). Schneider calls this "hyper-rationalism," in which facts are inferred without reliable supporting evidence and then interpreted within a synthetic analytical framework. This, he argues, characterises our analysis of autonomy in which we "discuss human behaviour without studying how people actually behave. It is the conceptualist's revenge for the world's complexity" (Schneider, 1998, xv). Sen, therefore, prefers to start from the world in which we live and to improve what we have today. He focuses on "actual realizations and accomplishments... including the kind of lives that people can actually lead..." (Sen, 2009, 10). Amongst the "non-idealists" Sen includes Adam Smith, Condorcet, Bentham, Marx and Mill. In place of theories based on abstract values, Sen favours practical choices and a framework for comparing actual outcomes which can accommodate ideas of "ecological rationality," discussed above. The starting point is not the abstract, but the range of policy challenges, opportunities and limitations presented now. Powers and Faden make this point in respect of health inequalities, ie that health policy should be made by reference to actual institutions, social practices and their impact on different people and groups. In this "non-ideal" theory, a fuller engagement with the human condition is crucial (Powers et al., 2006). Communitarian ideas identify most closely with this approach in which non-ideal, consequentialist and practicable solutions work together with the limitations of politics and public institutions.

Public health "ethics" are a good example of "non-ideal" theory. Non-ideal reasoning is better equipped to accommodate the sometimes competing "ideals" such as liberty and equality, autonomy and community, and public and private interests. For example, policy interventions aimed at individual behaviour range from passively monitoring current trends, to providing information and advice (ie on smoking and drinking), enabling and then guiding choice (eg in cigarette packaging), using tax incentives and disincentives to modify behaviour and ultimately of restricting and then eliminating choice (Nuffield Council on Bioethics, 2007, xix). Crucially, however, an over-emphasis on individual responsibility under-values the social and commercial determinants of inequality and dependency. Instead of starting with the individual, Daniels argues that community has the primary duty because: "our social responsibilities to promote and protect health have priority over our individual responsibilities... We can and should specify what we owe each other... independently of assessing the consequences of individual choices that affect our health" (Daniels, 2011, 279). The point of reappraising autonomy is not to impose the burden of non-communicable diseases upon those least able to shoulder it. It is to encourage the development of systems of governance, nationally and internationally, to promote equality of people's capabilities (Sen, 2009). For example, if paternalism is to limit public policy to "nudging" us toward healthier lives, it should be equally concerned to engage with the private, commercial forces nudging us towards ill-health (Dolan et al., 2010). Accepting behavourial psychologists' findings that we are constantly nudged from all directions, the question is not simply how governments should behave, it is which "nanny" do we prefer - publicly accountable government or self-interested private corporations? Yet, by permitting the "nanny industry" to dominate the debate, we impose vast personal and social cost on the community (Moore et al, 2015).

The starting point, therefore, is not an abstract ethical principle; it is an acceptable balance of competing outcomes and aspirations. Suggestions for improving equality and a proper balance between public and private interests are wide-ranging. They include 
regional measures to reduce tax avoidance, increased wealth redistribution, Torbin taxes on asset transfers, social responsibilities of company directors, employees on company boards, international regulation of financial services, a Social Progress Index to replace GDP as a measure of national prosperity, restoration of trade union bargaining rights, public investment in capital projects, jurisdiction over global corporations, and minimum standards of public services (see eg, Atkinson, 2015; Kay 2015; Ruggie, 2013; Sachs, 2011, Stiglitz, 2012). The point is not to prefer some over others, but to ascertain the public goods and services that enable the common wealth to promote the common benefit - to rebalance the relationship between staatsvolk and marktvolk. Heller refers to the challenge as the "the tragedy of the anticommons," in which property (tangible and intangible) is enclosed from public ownership and then misused by its private owners to expand inequality and disadvantage (Heller, in Bollier and Helfrich, 2013). ${ }^{9}$ Whether national politics is capable of responding to this economic challenge is disputed. On the one hand, Picketty believes that, "if we are to regain control of capitalism, we must bet everything on democracy..." (Picketty, 2014, 573). On the other, Rodrik doubts that democracy, nation states and global markets are capable of coexistence (Rodrik, 2012). Traditional notions of liberal autonomy, which quietly nudge so many assumptions in this debate, hinder efforts at a solution.

Perhaps we are beginning to review bioethics' fascination with the neoliberal paradigm of individualised autonomy where anxieties about the tyranny of medicine (Fitzpatrick, 2005) blind it to the tyranny of individualism (Shiell et al., 1996). Even the IMF is discussing whether neoliberalism has been "oversold" (IMF, 2016) and the World Bank is concerned about "inequality and shared prosperity" (World Bank, 2016). Policymakers may be encouraged that "bold moves by government that go against the grain of public opinion have been successful, not just in terms of affecting the behaviour, but also in shifting public opinion" (eg smoking bans) (Ipsos/MORI, 2012). Equally, while government acquiesces that it should "equip the citizen with an armoury of techniques to resist the influences that swirl around them," (Dolan et al., 2010), multinational manufacturers, including agricultural, retailing and pharmaceutical interests, together with anxiety about "food fascism" and "nannying" the public, hold the focus of responsibility firmly on individual behaviour to stifle more systemic responses (Marmot, 2015). An ideological preference for free-markets and small government has "captured" debate in a way that is widening inequality, weakening democracy and damaging the health of billions of people. (Kay, 2015, ch 8; Stiglitz, 2013, ch 9). WHO's estimates of the future expansion of the chronic diseases caused by obesity demonstrate how autonomy in its purified form is attractive only by ignoring its implications for economic and welfare dependency. A perfectly plausible, if contested, principle of bioethics has failed to differentiate itself from a partisan theory of politics which, itself, has become dominated by neoliberal approaches to economics. Some compare regulators' inactivity in this field to "the rebirth of social Darwinism" (Reich, 2012). Autonomy cannot be isolated from other important ethical values or the public interest. Non-ideal theory urges a practical and political view of what is feasible now and over time, without undue distortion by abstract ideologies which disempower governments and benefit the few. Without a paradigm shift in global responses to health inequality, the escalating costs of

$9 \quad$ Reminding us of an era more sympathetic to public goods and services, see J. Crawford (1946) discussing the UN's proposal for a World Food Board "to promote common welfare by ... raising levels of nutrition and standards of living..." 
non-communicable disease will continue to blight the lives of increasing numbers of people and render public welfare systems unsustainable.

\section{Acknowledgement}

With the usual disclaimer, the author thanks Professors Richard Ashcroft, Margot Brazier and John Coggon, Dr Amanda Warren-Jones and his colleague Dr Stuart Lakin, for their helpful comments on earlier drafts of this article.

\section{References}

Arantxa Colchero, M., Popkin, B., Rivera, J. and She Wen Ng (2016), 'Beverage Purchases from Stores in Mexico under the Excise Tax on Sugar Sweetened Beverages,' BMJ 2016; 352:h6704.

Atkinson, A. (2015), Inequality - What Can Be Done? London: Harvard University Press.

BAT. (2016), http://www.bat.com/group/sites/UK__ 9D9KCY.nsf/vwPagesWebLive/DOAA4G93 (accessed November 2016).

BAT, Philip Morris, JT, Gallagher and Imperial Tobacco v Secretary of State [2016] EWHC 1169.

BBC, 2016, "Obese patients denied surgery in a third of areas in England"

http://www.bbc.co.uk/news/health-36101302. (accessed May 2016).

Bayer, R, Gostin, L., Jennings, B. and Steinbock, B. (eds, 2007), Public Health Ethics Theory, Policy and Practice. Oxford: OUP.

Beauchamp, D. (2007), 'Community: The Neglected Tradition of Public Health,' in Bayer, R., Gostin, L., Jennings, and B. Steinbock, B. (eds) Public Health Ethics Theory, Policy and Practice. Oxford: OUP.

Berlin, I. (1969), Four Essays on Liberty. Oxford: OUP.

Bollier, D and Helfrich, D (2013), The Wealth of the Commons - the World Beyond Market and State. Amherst: Levellers Press.

Brazier, M. (2006), 'Do No Harm - Do Patients Have Responsibilities Too?' Cambridge Law Journal, 65: 400.

Brown, A. (2009), Personal Responsibility - Why it Matters. London: Continuum Publishing.

Coggon, J. (2007), 'Varied and Principled Understandings of Autonomy in English Law: Justified Inconsistency or Blinkered Moralism,' Health Affairs, vol 15, 235.

Coggon, J. (2012), What Makes Health Public? Cambridge: CUP.

Condliff v North Staffordshire PCT [2011] EWCA Civ 910.

Crawford, J. (1946), "Proposals for a World Food Board," The Australian Quarterly, 18, 5-18.

Daniels, N. (2008), Just Health - Meeting Needs Fairly. Cambridge: CUP.

Daniels, N. (2011), 'Individual and Social Responsibility for Health,' in Knight, C. and Stemplowska, Z. Responsibility and Distributive Justice. Oxford: OUP.

Daniels, N. Kennedy, B. and Kawachi, I. (2006), 'Health Inequality or, Why Justice is Good for Our Health,' in (eds) Anand, S., Peter, F. and Sen, A. Public Health, Ethics and Policy. Oxford: OUP. 
Dawson, A. and Verweij, M. (2009), Ethics, Prevention and Public Health. Oxford, OUP.

Dawson , A. (2010), 'The Future of Bioethics: Three Dogmas and a Cup of Hemlock,' Bioethics, 24: 218.

Deaton, A. (2007), 'Policy Implications of the Gradient of Health and Wealth,' in (eds) Bayer, R. Gostin, L. Jennings, B. and Steinbock, B. Public Health Ethics - Theory, Policy and Practice. Oxford: OUP.

Dawson, A. (2010), 'The Future of Bioethics: Three Dogmas and a Cup of Hemlock,' Bioethics, 24: 218.

de Shalit, A. (1995) Why Posterity Matters - Environmental Policies and Future Generations. London: Routledge.

Department of Health (2010), Enabling Effective Delivery of Health and Wellbeing, London.

Department of Health (2011), The Public Health Responsibility Deal, London.

Diamond, J. (2006) Collapse - How Societies Choose to Fail or Survive. London: Penguin Books.

Dolan, P. et al. (2010), MINDSPACE - Influencing Behaviour Through Public Policy. London: Cabinet Office, Institute for Government.

Dworkin, G. (1988), The Theory and Practice of Autonomy. Cambridge: CUP.

Dworkin, R. (2000), Sovereign Virtue - The Theory and Practice of Equality. Mass, Harvard University Press.

Dyer, C. (2015) 'Four Tobacco Companies Plan Action Against UK Government Over Standard Packaging,' BMJ 350: h2865.

Epstein, R. (2004), 'In Defense of the 'Old' Public Health,' Brooklyn Law Review 24: 1421.

European Commission (2015), Investment in TTIP and beyond - the path for reform.

Fitzpatrick, M. (2005), The Tyranny of Health-Doctors and the Regulation of Lifestyle. London: Routledge.

Friedman, C. et al. (2012), 'Cardiovascular Disease Risk in Healthy Children and its Association with Body Mass Index,' BMJ 345: e4759.

Friedman, M. (1970), "The Social Responsibility of Business is to Increase its Profits," The New York Times Magazine, 13 September 1970.

Gaylin, W. and Jennings, B. (2003), The Perversion of Autonomy - Coercion and Constraints in a Liberal Society. Washington: Georgetown University Press.

Le Grand, J. (2009) Incentives for Prevention. London: Health England Report No 3.

Gray, J. (2000) Two Faces of Liberalism. Cambridge: Polity Press, 102.

Gostin, L. and Gostin, K. (2009) 'A Broader Liberty: JS Mill, Paternalism and the Public's Health,' Public Health 123: 214.

Government Office for Science (2013) Foresight: Tackling Obesity. London: HMSO (2nd ed, ), 40.

Hardin, R. (1993) 'Blackmailing for the Mutual Good,' University of Pennsylvania Law Rev 141: 1786.

Hayek, F. (1976, republished 2013) Law, Legislation and Liberty: A New Statement of the Liberal Principles of Justice and Political Economy. Abingdon: Routledge.

Herring, J. (2016) Medical Law and Ethics. Oxford: OUP, 207-17.

Hashem, K., Haigh, C. and Powell, C. (2011), The Irresponsibility Deal. London: Children's Food Campaign. 
HMSO, Cm 7621 (2009), The Government's Response to the Health Committee Report on Health Inequalities, London.

Holland, S. (2007) Public Health Ethics. Cambridge: Polity Press.

Hurley, S. (2011) 'The Public Ecology of Responsibility,' in (eds) Knight, C. and Stemplowska, Z. Responsibility and Distributive Justice. Oxford: OUP.

Government Office for Science (2013) Foresight: Tackling Obesity (2nd ed), London.

House of Commons (2008-09), Health Inequalities, London: HC 286-1, Third Report, 2008-09, 26.

Home Office, (2010), 2010 Drug Strategy Consultation Paper (Home Office), 14.

IMF, (2016), 'Neoliberalism: Oversold?', Finance and Development 53, 2.

International Business Times, (2015), 14 May 2015, '20 global banks have paid \$235bn in fines since the 2008 financial crisis.'

Ipsos/MORI (2012), Acceptable Behaviour - Public Opinion on Behaviour Change Policy, London.

Jennings, B. (2009), 'Public Health and Liberty: Beyond the Millian Paradigm,' Public Health Ethics 2: 123.

JT International SA v Commonwealth of Australia [2012] High Court of Australia 43, http://www.austlii.edu.au/au/cases/cth/HCA/2012/43.html (accessed May 2016).

Kahneman, D. (2011), Thinking, Fast and Slow. London: Allen Lane.

Kahneman, D. Slovic, P. and Twersky, T. (eds) (1982) Judgment Under Uncertainty: Heuristics and Biases. Cambridge: CUP.

Kay, J. (2015), Other People's Money - Masters of the Universe or Servants of the People? London: Profile Books.

Kulick, A. (2012), Global Public Interest in International Investment Law, Cambridge: Cambridge University Press.

Le Grand, J. (2006), Motivation, Agency and Public Policy - of Knights \& Knaves, Pawns \& Queens, Oxford: Oxford: University Press,

Le Grand, J and New, B (2016), Government Paternalism - Nanny State of Helpful Friend? Woodstock: Princeton University Press.

Mazzucato, M. The Enterprise State, (2013), London: Anthem Press.

McGrady, B. (2011), Trade and Public Health - the WTO, Tobacco, Alcohol and Diet. Cambridge: Cambridge University Press.

McKeon, N (2015), Food Security Governance - Empowering Communities, Regulating Corporations. London: Routledge.

McLean, S. (2010), Autonomy, Consent and the Law. London: Routledge-Cavendish.

Marmot Review, (2010), Fair Society, Healthy Lives, London.

Marmot, M (2015) The Health Gap - the Challenge of Unequal World. London: Bloomsbury Press.

Martin, R. and Coker, R. (2006), 'Where Next?'. London: Public Health.

Martin, R. and Johnson, D. (2001), Law and the Public Dimension of Health. London: Cavendish.

Mechanic, D. (2010), 'Disadvantage, Inequality and Social Policy,' Health Affairs 21: 48.

Moore, A, Yeatman, H and Davey, R (2015), "Which Nanny - the State or Industry?" Public Health, 129: 1030-37.

Muller, J. (2002), The Mind and the Market - Capitalism in Western Thought. New York: Archer Books. 
Mulvaney-Day, N. and Womack, C. (2009), 'Obesity, Identity and Community: Leveraging Social Networks for Behaviour Change in Public Health,' Public Health Ethics 3: 250.

National Audit Office (2010-11), Tackling Inequalities in Life Expectancy in Areas with the Worst Health and Deprivation, HC 186, Session 2010-11, 4.

NCD Risk Factor Collaboration (2016), "Trends in adult body-mass index in 200 countries from 1975 to 2014," The Lancet, 387, 1377.

NHS Constitution (2015): London.

Nielsen, M. Landes, X. and Andersen, M. (2013), 'Should We Equalize Status in Order to Equalize Health?’ Public Health Ethics 6: 104.

NICE (2008, 2nd ed) Social Value Judgments - Principles for the Development of NICE. London.

NICE (2011), Public Health Guidance - Scope. London.

NICE (2012), Obesity: Working with Local People. London (draft guidance).

Office of Budget Responsibility (2012), Fiscal sustainability report 2012 - Executive summary. London.

Nuffield Council on Bioethics (2007), Public Health - Ethical Issues. London.

OECD (2009), Measuring Disparities in Health Status and In Access and Use of Health Care in OECD Countries, Paris: Working Paper, No 43, 18.

OECD (2015), The Labour Share in G20 Economies. Paris.

Oliver, A. and Ubel, P. (2014), 'Nudging the Obese: a UK-US consideration,' Health Economics, Policy and Law 9: 329.

O'Neill, O. (2002), Autonomy and Trust in Bioethics. Cambridge: CUP.

PCA Case No. 2012-12. http://www.pcacases.com/web/sendAttach/1711.

Patrick, P. (2008), 'Lose Weight or Lose Out: The Legality of State Medicaid Programs that make Overweight Beneficiaries Receipt of Funds Contingent upon Healthy Lifestyle Choices,' Emory Law Journal 58: 249.

Picketty, T. (2014), Capital in the Twenty-First Century. London: Harvard University Press.

Pogge, T. Rimmer M. Rubenstein K. (eds) (2010), Incentives for Global Public Health. Cambrdige: Cambridge University Press.

Polanyi, K. (1957), The Great Transformation. Boston, Mass: Beacon Press.

Porter, P. (2003), Blood and Guts - A Short History of Medicine. London: Penguin, Chs 1 and 2.

Powers, M. and Faden, R. (2006), Social Justice - The Moral Foundations of Public Health Policy. Oxford: OUP.

Powers, M., Faden, R. and Saghai, Y. (2012) 'Liberty, Mill and the Framework of Public Health Ethics,' Public Health Ethics 5: 6.

$R$ (Countryside Alliance and others) v Attorney-General [2007] UKHL 52, 111.

Reich, R. Beyond Outrage (2012). NY: Vintage Books, 67.

Rodrik, D. (2011), The Globalization Paradox. Oxford: OUP.

Ruggie, J (2013), Just Business - Multinational Corporations and Human Rights. London: WW Norton \& Co.

Sachs, J (2011), The Price of Civilisation - Economics and Ethics After the Fall. London: Bodley Head.

Sandell, M. (1998), Liberalism and the Limits of Justice. Cambridge: CUP, 2nd ed.

Sandell, M. (2012), What Money Can't Buy - The Moral Limits of Markets. Oxford: OUP. 
Scheffler, S. (2005), 'Choice, Circumstance and the Value of Equality,' Politics, Philosophy and Economics 4: 5.

Shrecker, T. (2016), 'Neolioberalism and Health: The Linkages and the Dangers,' Sociology Compass, 10, 1-20.

Shrecker, T and Bambra, C (2016), How Politics Makes Us Sick - Neoliberal Epidemics. London: Palgrave.

Schmidt, H. (2009), 'Personal Responsibility in the NHS Constitution and the Social Determinants of Health Approach,' Health Economics, Policy and Law 4: 129.

Schneider, C. (1998), The Practice of Autonomy - Patients, Doctors and Medical Decisions. Oxford: OUP.

Sen, A. (2006), 'Why Health Equity?', in (eds) Anand, S., Peter, F. and Sen, A. Public Health, Ethics and Policy. Oxford: OUP.

Sen, A. (2009), The Idea of Justice. London: Allen Lane.

Shiell, A. and Hawe, P. (1996), 'Community Development, Health Promotion and the Tyranny of Individualism,' Health Economics 5: 241.

Singer, P. (2015) 'Weigh More, Pay More,' http://www.projectsyndicate.org/commentary/weigh-more--pay-more (viewed, February, 2016).

Steen, E. et al. (2005), 'Impaired insulin and insulin-like growth factor expression and signaling mechanisms in Alzheimer's disease - is this type 3 diabetes?' Journal of Alzheimer's Disease 7: 63.

Stiglitz, J. (2013), The Price of Inequality. London: Penguin Books.

Stiglitz, J, (2016), The Euro and its Threat to the Future of Europe. London: Allen Lane.

Streek, W, (2014), Buying Time - the Delayed Crisis of Democratic Capitalism. London: Verso.

Swinburn, B, et al. (2011), 'The Global Obesity Pandemic: Shaped by Global Drivers and Local Environments,' The Lancet 378: 804.

Thaler, R. and Sunstein, C. (2009), Nudge. London: Penguin Books.

Van de Mussele v Belgium (ECtHR, 1983, App 8919/80, para 39.

UNCTAD (2015), Investment Policy Framework for Sustainable Development (United Nations, New York).

Van Harten, G. (2013) Sovereign Choices and Sovereign Constraints: Judicial Restraint in Investment Treaty Arbitration. Oxford: Oxford University Press.

Veitch, K. (2011), 'Solidarity and the Power of Contract,' J. Law and Society 30: 189.

Whitehead, M. (1988), Inequalities in Health - the Black Report and the Health Divide. London: Penguin Books (the Black report was originally published in 1980 and republished here).

Wilkinson, R. and Pickett, K. (2010), The Spirit Level - Why Equality is Better for Everyone. London: Penguin Books.

Wilson, J. (2011), 'Why it's Time to Stop Worrying About Paternalism in Health Policy,' Public Health Ethics 4: 269.

Winnipeg Child and Family Services (Northwest Area) v. G. (D.F.) [1997] 3 S.C.R. 925.

WHO (2005), WHO European Health Report: Geneva, 118.

WHO (2006), European Charter on Counteracting Obesity, Geneva.

WHO (2008), Action Plan for the Global Strategy for the Prevention and Control of Noncommunicable Diseases: Geneva.

WHO (2016), Global Report on Diabetes, Geneva. 
WHO (2016), Fiscal policies for diet and the prevention of noncommunicable diseases.

Geneva.

World Bank (2016), Inequality and Shared Prosperity,

http://www.worldbank.org/en/topic/isp (accessed 20 October 2016). 